\title{
Corrigendum: A deterministic model of a research organization's evolution and dynamics of performance
}

Prashant Goswami, Shiv Narayan Nishad and Dhanya Selvaratnam

Correction to: Palgrave Communications (2016) 1, Article number: 15012. doi: 10.1057/palcomms.2015.12; Published 9 Jun 2015; Updated 27 September 2016

The correct affiliation for Prashant Goswami has been added to the manuscript:

National Institute of Science, Technology and Development Studies (NISTADS), New Delhi, India

A note has been added to the acknowledgments section indicating the author's address at the time of acceptance for publication.

The article has been corrected online.

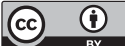

This work is licensed under a Creative Commons Attribution 4.0 International License. The images or other third party material in this article are included in the article's Creative Commons license, unless indicated otherwise in the credit line; if the material is not included under the Creative Commons license, users will need to obtain permission from the license holder to reproduce the material. To view a copy of this license, visit http://creativecommons.org/licenses/by/4.0/ 
